\title{
W SWOIM KOŚCIELE PAN OTWORZYŁ JEGO USTA (POR. SYR 15,5). ORĘDOWNICTWO ŚW. JANA APOSTOŁA I EWANGELISTY W ŚWIETLE FORMULARZY MSZALNYCH KOŚCIOŁA ZACHODNIEGO DO SOBORU TRYDENCKIEGO
}

\author{
IN HIS CHURCH THE LORD OPENED HIS MOUTH (CF. ECCL. 15,5). \\ INTERCESSION OF JOHN THE APOSTLE AND EVANGELIST \\ IN LIGHT OF MASS FORMULARIES USED IN THE WESTERN CHURCH \\ UNTIL THE COUNCIL OF TRENT
}

\begin{abstract}
From the first centuries the Christian cult of saints has been inseparably linked to the mystery of Christ. Particularly at the beginning, special veneration was given to the Mother of Jesus and to the closest disciples of Christ the Lord. One of these disciples of the Lord, belonging to the Twelve, whose cult has been known since the first centuries of Christianity, is St. John the Evangelist. In western tradition two feastdays are observed in his honor: the day of his birth into heaven, December 27, and the memorial of when he was given over to torture, May 6. Along with the biblical accounts, New Testament apocrypha played an important role in the formation of the cult of St. John. The biblical passages most often used in Mass formulas are the calling of St. John to be a fisher of men, his special relationship with Christ at the Last Supper, and the Mother of the Lord being entrusted into his care. In quoting his teaching, reference is often made to his proclamation of the Eternal Word, Who was with God from the beginning. A reading of the liturgical texts honoring St. John the Evangelist makes it possible to see this saint in the mystery of the Church as a model of union with Christ and with His Mother, and as an intercessor in the daily life of the faithful.
\end{abstract}

Key words: liturgy; veneration of saints; Eucharist; John the Apostle and Evangelist.

Od pierwszych wieków chrześcijaństwa kult świętych był nierozdzielnie związany z misterium Chrystusa. Zwłaszcza na początku oddawano szczególną cześć

Dr hab. WALDEMAR PAŁĘCKI MSF, prof. KUL - Kierownik Katedry Historii Liturgii w Instytucie Nauk Teologicznych KUL; adres do korespondencji - e-mail: wpalecki@kul.pl 
Matce Jezusa i najbliższym uczniom Chrystusa Pana ${ }^{1}$. Wprawdzie w pierwotnej wspólnocie chrześcijan nie znano oddzielnych wspomnień ku czci świętych, to jednak ze względu na konfrontację z otaczającą kulturą judaistyczną i pogańską znanym tam praktykom kultu herosów i wielkich mężów nadawano nową teologiczną treść ${ }^{2}$. Intensywny rozwój kultu świętych nastąpił w kolejnych wiekach. Od przełomu III i IV w. czczono ich jako szczególnych orędowników, a na rozwój kultu świętych wpłynęła literatura starotestamentalna i apokryficzna ${ }^{3}$. Zwłaszcza od czasów średniowiecza w kulcie świętych zwrócono uwagę na ich orędownictwo, o które proszono zwłaszcza w trudnych sytuacjach życia ${ }^{4}$.

Jednym z uczniów Pana należących do grona Dwunastu, którego kult znany był od pierwszych wieków chrześcijaństwa, jest św. Jan Ewangelista. Poddanie analizie historyczno-krytycznej formularzy mszalnych ku czci tego Świętego pozwoli uwypuklić najważniejsze treści teologiczne tego świętowania. Pomoże także wskazać na zachodzące różnice, czy też zmieniające się akcenty. Umożliwi to ukazanie jednocześnie wzajemnych zależności pomiędzy tekstami liturgicznymi, które należy postrzegać w kontekście kształtującego się w ciągu wieków kultu św. Jana Ewangelisty.

\section{1. ŚW. JAN APOSTOŁ I EWANGELISTA W LITURGII KOŚCIOŁA}

Umiłowanym uczniem Pana był św. Jan Apostoł i Ewangelista. Był on synem Zebedeusza i Salome, młodszym bratem Jakuba Starszego (por. Mt 4,21). Na początku był uczniem św. Jana Chrzciciela, ale wraz ze św. Andrzejem poszedł za Jezusem (por. J 1,35-40). Był on obecny podczas wydarzeń z życia Jezusa, jak przemienienie (por. Mk 9,2), wskrzeszenie córki Jaira (por. Mk 5,37) oraz pojmanie Jezusa w Ogrodzie Oliwnym (por. Mk 14,33). Podczas Ostatniej Wieczerzy św. Jan spoczywał na piersi Zbawiciela. Tylko on pozostał do końca wierny Jezusowi, dlatego Chrystus z krzyża powierzył mu pod opiekę swoją Matkę (por. J 19,26-27). Po zmartwychwstaniu Jezusa św. Jan przybył razem ze św. Piotrem jako pierwszy do grobu (por. J 20,8). Według opisów pozostałych ksiąg Nowego Testamentu św. Jan przebywał przez wiele lat w Jerozolimie

\footnotetext{
${ }^{1}$ Por. H. Auf der Maur, Feste und Gedenktage der Heiligen, w: H.B. MeYer (red.), Gottesdienst der Kirche. Handbuch der Liturgiewissenschaft, t. VI/1, Regensburg 1994, s. 268-269.

${ }^{2}$ Por. H. Fros, Kult świętych $w$ rozwoju historycznym $i$ w liturgii Kościoła, w: TENŻE, Wprowadzenie do Mszy o świętych, cz. 1, Warszawa 1980, s. 61-63.

${ }^{3}$ Por. Auf der Maur, Feste und Gedenktage, s. 84-88.

${ }^{4}$ Por. Z. Wit, Troska liturgiczna o człowieka chorego $w$ świetle polskich rytuałów potrydenckich (1631-1964), Lublin 1995, s. 191.
} 
(por. Ga 2,9), później najprawdopodobniej w Samarii i w Efezie, gdzie napisał Ewangelię i listy apostolskie. Kierował gminami chrześcijańskimi w Azji Mniejszej, do których - według listów z Apokalipsy - należały Efez, Smyrna, Pergamon, Tiatyra, Sardes, Filadelfia i Laodycea (por. Ap 2,1- 3,22) . $^{5}$ O pewnych wydarzeniach z życia św. Jana można dowiedzieć się od jego uczniów, do których należeli św. Papiasz (ok. 80-116) i św. Polikarp (zm. ok. 166) ${ }^{6}$.

Oprócz przekazów biblijnych szczegóły z życia św. Jana próbowały przedstawić apokryfy z pierwszych wieków chrześcijaństwa. Przykładem są gnostyckie Acta Joannis z II w. Według tego dzieła św. Jan miał głosić Ewangelię w Ziemi Świętej. Po wybuchu powstania żydowskiego schronił się w Zajordanii, a później w Azji Mniejszej ${ }^{7}$. Zgodnie z apokryfem powstałym pomiędzy IV a VI w., zatytułowanym Dzieje Jana w Rzymie, cesarz Domicjan (81-96), chcąc dowieść prawdomówności, kazał św. Janowi wypić zatruty napój. Do apokryficznych należy również podanie o poddaniu św. Jana torturom we wrzącym oleju. Św. Jan wszystkie te próby przeszedł zwycięsko, dlatego cesarz zmienił mu karę śmierci na zesłanie na wyspę Patmos ${ }^{8}$. Według Dziejów świętego Apostoła i Ewangelisty Jana Teologa, spisanych przez jego ucznia Prochora, które powstały pomiędzy V a VII w., uczniowie, którzy pochowali św. Jana, po powrocie znaleźli pusty grób ${ }^{9}$. Spekulatywne opisy dziejów św. Jana z pewną ironią ocenił św. Augustyn (zm. 430) w słowach: „Niech taki twierdzi, że apostoł Jan żyje, i że w onym grobowcu, który jest koło Efezu raczej śpi, a nie leży pochowany. Niech się powoła jakby na dowód, iż, jak opowiadają, ziemia tam lekko jakby drży i się burzy i że się to dzieje z tego powodu, iż (Jan) oddycha, i może o tym tak twierdzić stale i uparcie" ${ }^{\prime 10}$.

Do istotnych kwestii związanych z kultem św. Jana należy dzień świętowania. W kulcie świętych istotnym powodem obchodu był dzień narodzin dla nieba danego świętego. Kult św. Jana, według najstarszych źródeł, powraca do przekazów z Efezu, gdzie utrwalono, że przejście do nieba miało miejsce 26 września $^{11}$. Początkowo w Grecji obchodzono wspólnie święto ku czci świętych Jana i Jakuba 27 grudnia, a powodem mogła być dedykacja ku ich czci kościoła w Konstantynopolu. W Palestynie obchodzono wspomnienie ku czci św. Jana 29 grudnia,

\footnotetext{
${ }^{5}$ Por. H. Fros, F. Sowa (opr.), Księga imion i świętych, t. III, Kraków 1998, kol. 208-209.

${ }^{6}$ Por. L. Stachowiak, Jan apostot Ewangelista. I. W Piśmie św., EK VII, kol. 753.

${ }^{7}$ Por. M. STAROwIEYSKI (red.), Apokryfy Nowego Testamentu, t. II, cz. I, Kraków 2017², s. 294-338.

${ }^{8}$ Por. tamże, s. 342-345.

${ }^{9}$ Por. tamże, s. 408.

${ }^{10}$ Św. AuguSTYN, Homilie na Ewangelie i Pierwszy list Św. Jana, cz. II, (Pisma starochrześcijańskich pisarzy, t. XV), Warszawa 1977, s. 369.

${ }^{11}$ Por. M. RighetTI, L'anno Liturgico, (Manuale di storia liturgica, t. II), Milano 1969, s. 89.
} 
natomiast u Ormian 28 grudnia $^{12}$. O świętowaniu ku czci św. Jana z racji Narodzenia Pańskiego wspominał św. Grzegorz z Nyssy (zm. ok. 394) w mowie pogrzebowej ku czci św. Bazylego Wielkiego (zm. 379) ${ }^{13}$. W Martyrologium św. Hieronima (zm. ok. 419) święto to zostało wpisane pod dniem 27 grudnia jako: Adsumptio sancti Iohannis evangelistae apud Ephesum et ordinatio episcopatus sancti Iacobi fratris Domini, qui ab apostolis primus ex Iudaeis Hierosolimis est episcopus ordinatus et medio pascha martyrio coronatus ${ }^{14}$. Ten dzień obchodzono nie tyle jako dzień narodzin dla nieba, ale jako wspomnienie jego powrotu z wyspy Patmos. Innym powodem świętowania mogła być dedykacja kościoła w Efezie ku jego czci ${ }^{15}$.

Tradycja obchodzenia święta ku czci św. Jana Ewangelisty na Zachodzie sięga V w. W Rzymie oddawano cześć św. Janowi zaraz po świętych Piotrze i Pawle. Według Księgi Pontyfików papież Hilary (461-468) zbudował trzy oratoria w baptysterium bazyliki na Lateranie: ku czci św. Jana Chrzciciela, św. Jana Ewangelisty i Świętego Krzyża, bogato je uposażając ${ }^{16}$. Świadectwem obchodzenia święta 27 grudnia są najstarsze sakramentarze, jak Libella z Werony. Dzień narodzin dla nieba św. Jana w sposób symboliczny próbowali przedstawić teologowie średniowiecza. Punktem wyjścia było porównanie dnia narodzin św. Jana Chrzciciela 24 czerwca (przesilenie letnie) z 27 grudnia (przesilenie zimowe). Według Honoriusza z Autun (zm. ok. 1150), właśnie 24 czerwca był dniem narodzin dla nieba. Ze względu jednak na kult św. Jana Chrzciciela Kościół postanowił obchodzić wspomnienie powrotu św. Jana z wygnania lub dedykacji Kościoła w Efezie ku jego czci ${ }^{17}$. Ten pogląd podzielał Jan Beleth (zm. ok. 1183), który wspominał o sprawowaniu w wigilię narodzin św. Jana Chrzciciela drugiej mszy ku czci św. Jana Ewangelisty ${ }^{18}$, czy Wilhelm Durand (zm. 1296) ${ }^{19}$.

\footnotetext{
${ }^{12}$ Por. M. STRASZEWICZ, Jan apostot Ewangelista. II. Kult, EK VII, kol. 753.

${ }^{13}$ Por. Gregorius Nyssenus, Oratio funebris qua fratris sui Basilii Magni laudes et memoriam concelebrat, $\mathrm{PG} 46,789$ (787-818).

${ }^{14}$ Por. Acta Sanctorum Novembris, collecta digesta illustrata, a Carolo de Smedt, Iosepho de Backer, Francisco van Ortroy, Iosepho van den Gheyn, Hippolyto Delehaye \& Alberto Poncelet, Societatis Iesu Presbyteris. Tomi II pars prior, qua dies tertius partim et quartus continentur praemissum est Martyrologium Hieronymianum edentibus Iohanne Baptista de Rossi et Ludovico Duchesne, Bruxellis 1894, s. [2].

${ }^{15}$ Por. M. STRASZEwiCZ, Jan apostot Ewangelista. II. Kult, EK VII, kol. 753.

${ }^{16}$ Por. Księga Pontyfików 1-96, (Synody i Kolekcje Praw, IX), opr. M. Ożóg, H. Pietras, Kraków 2014, s. 115*-116*.

${ }^{17}$ Por. Honorius Augustodunensis, Gemma animae sive de divinis officiis et antiquo ritu missarum, deque horis canonicis et totius annis solemnitatibus, PL 172, 646 (541-737).

${ }^{18}$ Por. Joannes Belethus, Rationale divinorum officiorum, PL 202, 142 (9-166).

${ }^{19}$ Por. Gvillelmi Dvranti Rationale divinorvm officiorvm, VII-VIII, wyd. kryt. A. Davril, T.M. Thibodeau, Turnhout 2000, s. 55.
} 
Drugie święto liturgiczne ku czci św. Jana Ewangelisty obchodzono 6 maja i określane było jako ante portam Latinam. Związane one było $\mathrm{z}$ podaniem apokryficznym, według którego św. Jan miał zostać wrzucony do kotła z gorącym olejem i przetrwać tę próbę męczeństwa. Innym motywem legendarnym świętowania tego dnia ku czci św. Jana było odnalezienie 6 lub 8 maja manny na jego grobie $^{20}$. Święto to na Zachodzie obchodzono od VIII w., a świadkiem jest Sakramentarz Gregoriański typu hadriańskiego z 780 r. Święto to było obecne w tradycji Kościoła łacińskiego do reformy Codexu Rubricarum i zostało zniesione 25 lipca 1960 r. $^{21}$

Oprócz celebrowania świąt ku czci św. Jana we wczesnym średniowieczu był on wzywany jako opiekun przed zagrożeniami morskimi, a świadczy o tym bazylika w Rawennie wzniesiona w 425 r., jako wotum uratowania żeglarzy uciekających z Konstantynopola do Włoch ${ }^{22}$. Św. Janowi przypisywano również moc uzdrawiania przed ukąszeniem zwierząt i zatrutymi napojami. Zgodnie z legendą, która powstała w Galii około VI w., św. Jan chcąc nawrócić w Efezie pogańskiego kapłana Arystodema zgodził się na wypicie zatrutego napoju. Próbę tę przeszedł on pomyślnie, a sam kapłan pogański przyjął chrzest wraz $\mathrm{z}$ całym ludem. W nawiązaniu do tej legendy początkowo błogosławiono napoje przeciw truciźnie (contra venenum), a następnie wino ku czci św. Jana jako znak miłości (benedictio amoris S. Johannis). Zwyczaj ten był powszechnie praktykowany od $\mathrm{X} \mathrm{w.}{ }^{23} \mathrm{~W}$ tradycji Kościoła fundamentem jednak celebracji liturgicznej są teksty mszalne przeznaczone na święta św. Jana.

\section{2. ŚWIĘTO IN NATALE SANCTI IOHANNIS EVANGELISTAE}

Najstarszym świętem ku czci św. Jana Ewangelisty, obchodzonym na Zachodzie, było święto In Natale, które przypadało 27 grudnia. Teksty liturgiczne, przeznaczone na Mszę Świętą, zostały zapisane w tzw. sakramentarzach, które zawierały modlitwy dla celebransa ${ }^{24}$. Jednym $z$ najstarszych zachowanych sakramentarzy jest kodeks z Werony z VI w. ${ }^{25} \mathrm{~W}$ manuskrypcie tym występują

\footnotetext{
${ }^{20}$ Por. M. STRASZEWICZ, Jan apostot Ewangelista. II. Kult, EK VII, kol. 753.

${ }^{21}$ S. Congregatio RituUm, Variationes in Breviario et Missali Romano ad normam novi Codicis Rubricarum, AAS 52(1960), s. 707 [706-721].

${ }^{22}$ Por. M. RighetTi, L'anno Liturgico, s. 89.

${ }^{23}$ Por. A. Franz, Die kirchlichen Benediktionen im Mittelalter, t. I, Freiburg 1909, s. 298-301.

${ }^{24}$ Por. W. PAŁĘCKI, Sakramentarz, EK XVII, Lublin 2012, kol. 901-903.

${ }^{25}$ Por. J.W. Boguniowski, Rozwój historyczny ksiag liturgii rzymskiej do Soboru Trydenckiego i ich recepcja w Polsce, Kraków 2001, s. 59-62.
} 
dwa formularze mszalne przeznaczone na święto św. Jana Apostoła i Ewangelisty, obchodzone 27 grudnia $^{26}$. Zamieszczone zostały w sekcji 41 zatytułowanej: In natale sancti Iohannis Euangeliste apostoli. Pierwszy z tych formularzy rozpoczyna się od oracji: Omnipotens sempiterne deus..., w której proszono wszechmogącego i wiecznego Boga, aby obchodząc święto św. Jana Ewangelisty udzielił Kościołowi łaski, aby ukochał to, w co On wierzył i głosił to, czego nauczał. Również w innej oracji: Deus, qui per os beati apostoli tui Iohannis euangeliste... celebrans prosił, aby mogli zrozumieć w sposób właściwy naukę przekazaną przez św. Jana. O to szczególne wstawiennictwo proszono Pana składając dary ofiarne, kiedy odmawiano modlitwę: Munus populi tui, domine... Kapłan prosił, aby wstawiennictwo świętych sprawiło, że składany dar będzie miły dla Pana.

Motywy do uwielbienia za dzieła zdziałane w życiu św. Jana podano w prefacji. Wspominano tu wydarzenia z jego życia od momentu, kiedy został powołany przez samego Jezusa Chrystusa. On wzgardził ziemskim ojcem, aby mógł posiąść niebiańskiego. On też odrzucił ziemskie sieci, aby łowić dusze zanurzone w czystych wodach jego nauki. Wspominano moment, kiedy św. Jan w czasie ostatniej Wieczerzy spoczywał na piersi Jezusa oraz kiedy została jemu powierzona pod opiekę Maryja - Matka Jezusa. Podczas celebracji Mszy św. podkreślano także w prefacji, że to św. Jan ogłaszał naukę o Słowie, które od początku było u Boga. Na wieczne zbawienie, dzięki wsparciu apostolską nauką i modlitwami, proszono słowami modlitwy: Presta nobis, domine... Natomiast w ostatniej modlitwie Prosequere, domine... zwracano się do Pana, aby wejrzał On na swój lud, aby radował się zarówno pociechą doczesną jak też doświadczył w wieczności Jego miłosierdzia.

Wiarę w skuteczność wstawienniczej modlitwy św. Jana podkreśla oracja drugiego formularza mszalnego. Według modlitwy: Natalicia sancti Iohannis... to wsparcie św. Jana miało przyczyniać się do wiernego zachowania nauki świętego Jana. Podobnie motyw czerpania nauki z Ewangelii, którą pozostawił św. Jan, wybrzmiewa w modlitwie nad darami: Supplicationibus apostolicis... Tym podstawowym przesłaniem Ewangelii św. Jana była prawda, że na początku było Słowo i Słowo było u Boga, co też podkreśla prefacja drugiego formularza. Wychwalając tę prawdę podkreślano, że oznacza ona wieczność bez początku, odrębność osób i jedność w Bóstwie. Tym prawdom mieli być posłuszni Ci, którzy celebrują święto ku czci św. Jana, na co zwracał uwagę tekst modlitwy po Komunii św.: Miserator et misericors domine... Pan bowiem nie opuszcza wiernych, ale staje się bliski poprzez sakramenty. W modlitwie nad ludem Aeclesiam tuam... celebrans natomiast prosił, aby Kościół doszedł do tych darów, które Pan obiecał wiernym.

\footnotetext{
${ }^{26}$ Por. L. EIZENhÖFER, P. Siffrin, L.C. Mohlberg, Sacramentarium Veronense (Cod. Bibl. Capit. Veron. LXXXV [80]), Roma 1994, s. 163-164.
} 
Drugim ważnym świadkiem liturgii mszalnej ku czci św. Jana Apostoła i Ewangelisty jest Sakramentarz Gelazjański Starszy z ok. VII w., kodeks sięgający w swej treści pierwszych pięciu wieków chrześcijaństwa ${ }^{27}$. W porównaniu z wcześniejszym zbiorem formularzy z Werony w sakramentarzu tym występuje jeden formularz przeznaczony na 27 grudnia i obejmuje sekcję $7 \mathrm{w}$ pierwszej części tej księgi i jest zatytułowany: In Natale Sancti Iohannis Euangelistae. VI Kalendas Ianuarias ${ }^{28}$. Pierwsza z tych oracji: Deus, qui per os beati apostoli tui Iohannis... była zamieszczana w Libelli z Werony. Do znanych tekstów należała również secreta: Supplicationibus apostolicis beati Iohannis... Pośród nowych tekstów zapisano modlitwę: Deus, qui beati Iohannis..., w której celebrans prosił o łaskę, aby wierni mogli za wstawiennictwem św. Jana Ewangelisty dojść do poznania Odwiecznego Słowa. Kontynuacją tej myśli jest wezwanie skierowane w modlitwie: Praesta, quaesumus..., aby nie tylko poznać to Słowo, ale również je głosić w swoim życiu. Celem tego miało być uzyskanie, dzięki zasługom św. Jana Ewangelisty, odpuszczenia kar, na co zwraca uwagę modlitwa po Komunii św.: Beati aeuangelistae Iohannis... W ostatniej modlitwie tego formularza nad ludem: Adsit aecclesiae tuae... celebrans prosił, aby św. Jan Ewangelista, jako wieczny nauczyciel, nie ustawał w swym orędownictwie. Oprócz tych formularzy znane były teksty, które stanowiły kompilację tych dwóch źródeł. Przykładem jest sakramentarz z Pragi, w którym oracja dnia: Deus, qui per os beati apostoli... i modlitwa nad darami: Supplicationibus apostolicis beati Iohannis euangelistae... pochodzą z Libelli z Werony, natomiast modlitwa po Komunii św. (ad complendum): Beati euangelistae Iohannis... z Sakramentarza Gelazjańskiego Starszego.

Wśród sakramentarzy od VIII w. ważną rolę odegrał Sakramentarz Gregoriański, który został przesłany przez papieża Hadriana I (772-795) na dwór Karola Wielkiego (zm. 814) ${ }^{29}$. W księdze tej na dzień 27 grudnia znajduje się w sekcji 11 jeden formularz ku czci św. Jana: VI Kalendas Ianuarias. Id Est XXVII Die Mensis Decembris. Natale Sancti Iohannis Euangelistae ${ }^{30}$. Były to teksty nowe, dotąd nieznane. W oracji: Ecclesiam tuam domine... celebrans prosił, aby Pan oświecał swój Kościół, aby dzięki naukom św. Jana Ewangelisty osiągnął dobra wiekuiste. Podobnie w modlitwie nad darami Suscipe munera... wstawiennictwo św. Jana miało przyczynić się do wyzwolenia wiernych od zła.

\footnotetext{
${ }^{27}$ Por. J.W. Boguniowski, Rozwój historyczny ksiag, s. 73.

${ }^{28}$ Por. L.C. MohlBerg, Liber Sacramentorum Romanae Aeclesiae ordinis anni circuli (Cod. Vat. Reg. lat. 316/Paris Bibl. Nat. 7193, 41/56 Sacramentarium Gelasianum), Roma 1960, s. 11-12.

${ }^{29}$ Por. J.W. Boguniowski, Rozwój historyczny ksiag, s. 78.

${ }^{30}$ Por. J. Deshusses, Le Sacramentaire Gregorien. Ses Principales Formes d'apres les plus anciens Manuscrits, v. 1, Fribourg 1971, s. 108-109.
} 
Także w modlitwie po Komunii św.: Refecti cibo potuque caelesti... po pokrzepieniu niebiańskim pokarmem i napojem, kapłan prosił, aby modlitwy św. Jana broniły wiernych.

W Sakramentarzu Gregoriańskim - Hadriańskim w sam dzień święta umieszczono jeszcze pięć modlitw, które odmawiano podczas nieszporów. W tekstach tych wybrzmiewają również niuanse dotyczące wstawiennictwa św. Jana. W modlitwie Beati iohannis domine... celebrans prosił o wyjednanie przebaczenia i wieczne zbawienie. Również w modlitwie ad fontes: Beati euangelistae iohannis... błagano, aby wierni otrzymali to, czego sami nie mogą otrzymać, albo, by obficie wysłuchał, jak zapisano to w modlitwie: Sit domine beatus iohannes euangelista... Ostatnie modlitwy, występujące w Sakramentarzu Gregoriańskim - Hadriańskim, Deus qui per os beati apostoli... oraz Omnipotens sempiterne deus..., znano już z Libelli z Werony.

Księgi, używane w Rzymie, przesłane na dwór Pepina Małego i Karola Wielkiego, posłużyły do skompilowania nowych ksiąg, które uzupełniano nowymi tekstami. W ten sposób powstawały księgi zwane Sakramentarzami Gelazjańskimi Młodszymi albo Sakramentarzami Gelazjańskimi z VIII w. ${ }^{31}$ Przykładem tego typu księgi jest Sakramentarz z Monza datowany na IX-X w. Występujący tu formularz mszalny na dzień 27 grudnia stanowił kompilację z Libelli z Werony oraz z Sakramentarza Gregoriańskiego - Hadriańskiego ${ }^{32}$. Z pierwszego źródła pochodziła oracja oraz fragment prefacji. $\mathrm{Z}$ ostatniego natomiast zaczerpnięto sekretę oraz postcomunio. Do tego typu sakamentarzy należy również Sacramentarium Triplex, stanowiący amalgran Sakramentarza Gelazjańskiego, Gregoriańskiego oraz Ambrozjańskiego ${ }^{33}$. W zbiorze tym znajdują się $\mathrm{dwa}$ formularze ku czci św. Jana ${ }^{34}$. Z Libelli z Werony zaczerpnięto tu orację, Deus qui per os beati apostoli..., prefację, oraz Omnipotens sempiterne deus... Z Sakramentarza Gelazjańskiego Starszego pochodzi inna modlitwa po Komunii św.: Assit ecclesiae tuae... oraz Praesta quaesumus omnipotens deus..., a także sześć modlitw z Sakramentarza Gregoriańskiego - Hadriańskiego. Druga msza z tego zbioru pochodziła z tradycji ambrozjańskiej. Znajduje się tutaj pięć oracji do wyboru, z których dwie znane były z Libelli z Werony: Deus qui per os... oraz: Ecclesiam tuam... Z Sakramentarza Gelazjańskiego Starszego zaczerpnięto natomiast modlitwy: Praesta quaesumus... oraz Assit

\footnotetext{
${ }^{31}$ Por. J.W. BoguniowsKi, Rozwój historyczny ksiąg, s. 75.

${ }^{32}$ Por. A. Dold, K. GAMBER, Das Sakramentar von Monza (Im cod. F1/101 der dortigen Kapitelsbibliothek), Beuron 1957, s. 4*.

${ }^{33}$ Por. J.W. Boguniowski, Rozwój historyczny ksiag, s. 76.

${ }^{34}$ Por. O. Heiming, Das Sacramentarium Triplex. Die Handschrift C 43 der Zentralbibliothek Zürich, B. I-II, Münster 1968-1983, s. 23-25.
} 
ecclesiae tuae.... Do własnych tekstów należała natomiast oracja Praesta quaesumus omnipotens deus... W modlitwie celebrans prosił, aby za wstawiennictwem św. Jana Słowo, które stało się Ciałem, dzięki misterium Eucharystii, zawsze zamieszkało wśród wiernych. Secreta oraz prefacja miała swoje źródło w Libelli z Werony. Do własnych należała natomiast modlitwa na zakończenie: Apostolica beati Iohannis... Proszono w niej o ogólną pomoc św. Apostoła, ku którego czci sprawowano liturgię w to święto.

Interesującym zagadnieniem jest kult liturgiczny św. Jana Apostoła i Ewangelisty w Kościele zachodnim w liturgii pozarzymskiej. Przykładem jest liturgia gallikańska, która została utrwalona w Missale Gothicum z VII w. ${ }^{35}$ Według tej księgi 27 grudnia obchodzono dzień narodzin dla nieba dwóch braci: Jana i Jakuba. Według kronikarzy bizantyńskich Filipa z Sydy (V w.) i Jana Grzesznika (IX w.) mieli oni ponieść śmierć męczeńską podczas prześladowań $\mathrm{w} 44 \mathrm{r}^{36}$ Formularz, przeznaczony na święto św. Jana, znajduje się w sekcji 6 i jest zatytułowany: Missa In Natale Apostolorum Jacobi, et Johannis ${ }^{37}$. Formularz, przedłożony w tej księdze liturgicznej, rozpoczyna się od wprowadzenia (praefatio) w misterium tego dnia. Kapłan wychwalał dzień, w którym wybrał św. Jakuba i Jana jako niezwykłą ozdobę apostołów i męczenników. W formularzu tym podkreślano motyw męczeństwa obydwóch apostołów, na co wskazano w modlitwie: Domine, qui beatissimis apostolis Jacobo et Johanni... Wstawiennictwo i opieka tych świętych miały pomóc w osiągnięciu miłosierdzia Boga.

Do własnych zwyczajów liturgii galijskiej należy modlitwa Post nomina, którą odmawiano podczas przygotowania darów ofiarnych. Miała ona na początku charakter wezwania i zachęty wiernych do wspólnej modlitwy. Na dzień św. Jakuba i Jana rozpoczynała się od słów: Domine, quem vocantem sancti apostoli Jacobus et Johannes.... Wspominając powołanie tych świętych do bycia rybakami ludzi, kapłan prosił, aby Pan wysłuchał modlitwę, by wierni przynajmniej starali się naśladować ich napomnienia. Zaraz po tej modlitwie odmawiano modlitwę ad pacem, gdyż znak pokoju przekazywano jeszcze przed anaforą. Rozpoczynając od wezwania: Dimine aeterne... kapłan, wspominając życie świętych apostołów, prosił Pana o łaskę zmiłowania, aby według ich przykładu trzymali się wiary i nauczyli się miłości.

Modlitwa eucharystyczna, czyli anafora, podobnie jak w liturgii rzymskiej rozpoczynała się od prefacji, nazywanej immolatio. Wychwalano Boga za świętych, których Pan przeznaczył na to, aby stali się na obraz Jego syna. Za

\footnotetext{
${ }^{35}$ Por. B. NADOLSKI, Galijski ryt, EK V, Lublin 1989, kol. 821-822.

${ }^{36}$ Por. M. StarowieYSKI (red.), Apokryfy Nowego Testamentu, t. II, cz. I, Kraków 2017², s. 289.

${ }^{37}$ Por. L.C. Mohlberg (wyd.), Missale Gothicum (Vat. Reg. lat. 317), Roma 1961, s. 12-14.
} 
wstawiennictwem tych świętych i za przykładem samego Pana, który przez krzyż zwyciężył śmierć, błagano, aby Pan udzielił łaski miłosierdzia i wysłuchał modlitwy. Pan bowiem jest dla wszystkich świętych mocą i chwałą, zwycięstwem męczenników i koroną, pasterzem owiec, ofiarą kapłanów, zbawieniem narodów i ofiarą przebłagalną za grzechy. $\mathrm{Z}$ tym tekstem bezpośrednio związane było zmienne Post sanctus. Wychwalano w nim Chrystusa, który przyjął na siebie śmierć i grzechy, aby osiągnąć zwycięstwo. Święci apostołowie są bowiem świecznikami w Kościele, którzy oświecają wiarę innych, jak określa modlitwa błogosławieństwa nad ludem. Motyw wstawiennictwa tych świętych pojawia się również w modlitwie post communionem: Repleti, Domine... oraz collectio: Apostolorum, quaesumus, Domine... Była to szczególna prośba o uzyskanie miłosierdzia Boga oraz by umieli przyjąć święte dary od samego Boga.

Do pozarzymskich liturgii Kościoła zachodniego należy ryt wizygocki zwany również mozarabskim, który ukształtował się na półwyspie Iberyjskim ${ }^{38}$. Na początku XVI w. kardynał Franciszek Ximénes de Cisneros (zm. 1517) uporządkował ten ryt wydając drukiem w $1500 \mathrm{r}$. mszał zwany mozarabskim, gdzie zamieszczono własne teksty ku czci św. Jana Ewangelisty ${ }^{39}$.

Formularz ku czci św. Jana Apostoła i Ewangelisty, zamieszczony w wizygockim mszale, rozpoczyna się od antyfony: Gloriam et magnum decorem impones super eum... (Ps 21 [20], 6-7. 5). Do św. Jana odniesiono tu słowa psalmu, że Pan ozdobił go blaskiem i dostojeństwem. Po hymnie Gloria in excelsis Deo kapłan odmawiał modlitwę, jak w sam dzień Narodzenia Pańskiego. Ten Bóg, który jest chwałą wiernych, jest równocześnie ogłaszany w niebiosach przez aniołów, opiewany na wieki, uroczyście i z wiarą wielbiony w czasie liturgii. Kapłan prosił, aby wierni zostali uwolnieni od własnych grzechów i mogli wiecznie Go sławić w Jego chwale. W tradycji starohiszpańskiej obficiej zastawiony był stół słowa. Pierwsze czytanie, zaczerpnięte z Księgi Mądrości (10,10-18), koresponduje z powołaniem św. Jana, którego mądrość powiodła go prostymi ścieżkami i dała mu znajomość rzeczy świętych. Bóg bowiem dał się poznać, co podkreślały słowa psalmu (Ps 76 [75], 2-3). O podstawach kerygmatu głoszonego przez apostołów przypomniano w drugim czytaniu. Dotyczył on prawdy o śmierci i zmartwychwstaniu z Chrystusem i Jego paruzji (1 Tes 4,13-17). Ewangelia przypominała wydarzenia po zmartwychwstaniu, kiedy Jezus zadał pytanie dotyczące miłości względem siebie (J 21,15-24). Motyw uwielbienia i wywyższenia Boga podejmował natomiast śpiew Alleluja wykonywany po Ewangelii (Ps 118 [117], 28).

\footnotetext{
${ }^{38}$ Por. A. HeINZ, Liturgien. IV. Abendländische Liturgien. 2. Altspanische Liturgie, LThK VI, Freiburg im Breisgau 1997, kol. 982-983.

${ }^{39}$ Por. Liturgia mozarabica secundum regulam beati Isidori. Missale Mixtum, PL 85, 199-205.
} 
Liturgia eucharystyczna $\mathrm{w}$ dzień św. Jana rozpoczynała się od śpiewu sacrificium: Omnis qui me confessus fuerit... czyli odpowiednika offertorium w liturgii rzymskiej. Zapewniano, powołując się na teksty Ewangelii według św. Mateusza, że kto się przyzna przed Panem, On również przyzna się przed nim przed Ojcem w niebie (por. Mt 10,32). Warunkiem jest jednak paradoks ewangeliczny: „Bo kto chce zachować swoje życie, straci je; a kto straci swe życie z mego powodu, znajdzie je" (Mt 16,25). Bycie bowiem uczniem Jezusa zakłada całkowite oddanie się w ręce Boga ${ }^{40}$. W dwóch modlitwach, które znajdowały się w tym mszale do wyboru, wybrzmiewały również aspekty dotyczące wstawiennictwa św. Jana. W pierwszej z nich: Considerantes dilectissimi fratres..., kapłan prosił, aby św. Jan okazał się dobrym patronem, jak był umiłowanym uczniem. On bowiem podczas Ostatniej Wieczerzy, spoczywając na piersi Pana, otrzymał od niego dar wiedzy. Podobnie w drugiej modlitwie do wyboru: Genite ingeniti filius Dei summi... autor sięgnął do tego motywu, kiedy św. Jan spoczywał na piersi i czerpał nadprzyrodzoną wiedzę jak ze źródła. Podstawą modlitwy było pragnienie, aby człowiek mógł poznać słabość swojej natury i dojść do poznania Jego boskości. Wstawiennictwo św. Jana miało zmienić obyczaje wiernych na lepsze, poskromić zarazę, zniszczyć choroby, oddalić klątwy, zniweczyć wszystko, co sprzeciwia się wierze chrześcijańskiej, a to, co szczęśliwe - umocnić i tak dojść do posiadania dóbr wiecznych. Ponadto miało ono wstrzymać głód, uspokoić spory, oddalić herezje. Wstawiennictwo to miało dotyczyć również całego stworzenia, dlatego proszono, aby ziemia wydała owoce.

$\mathrm{W}$ tradycji wizygockiej, podobnie jak w galijskiej, znano modlitwę post nomina. W modlitwie tej: Jesu Rex noster et Domine... za wstawiennictwem św. Jana błagano Jezusa, jako króla i Pana, aby składana ofiara - lekarstwo Chrystusa - przyczyniła się do podniesienia dusz do życia w cnocie, a zmarłych uwolniła od kary. Także w modlitwie Novimus Domine..., przed przekazaniem znaku pokoju, ponownie przywoływano motyw spoczywania św. Jana na piersi Jezusa. Wspominając te wydarzenia celebrans prosił, aby Pan napełnił wiernych tą nauką, którą głosił św. Jan. W ten sposób wierni mieli zasłużyć na to, aby zostali umiłowani przez Pana, a żyjąc w pokoju osiągnęli pełnię pokoju oraz obfite błogosławieństwo.

Podczas modlitwy eucharystycznej w liturgii wizygockiej przewidziano wiele tekstów własnych. Do jednych z pierwszych należała zmienna prefacja, czyli inlatio. Motywem do dziękczynienia Bogu były zasługi świętych. Pośród nich jaśniał św. Jan Ewangelista, który nauczał o Odwiecznym Słowie. Jemu to Jezus,

\footnotetext{
${ }^{40}$ Por. A. LeSke, Ewangelia wedtug św. Mateusza, w: Międzynarodowy komentarz do Pisma Świętego, red. W.R. Farmer, Warszawa 2001, s. 1186.
} 
wisząc na krzyżu, powierzył swoją Matkę. On też został zachowany przez Pana przed poniesieniem męczeńskiej śmierci, a obecnie jaśnieje $\mathrm{w}$ chórze pośród aniołów. Po prefacji występowały jeszcze dwie części zmienne w modlitwie eucharystycznej: post sanctus i post pridie. W pierwszej z nich podkreślano również motyw, kiedy Jan spoczywał na piersi Pana podczas Ostatniej Wieczerzy i otrzymał on niego naukę. W ten sposób doszedł on do głoszenia wiecznego początku, którego nikt nie mógł przeniknąć. Podobnie, wspominając oddanie w jego opiekę Maryi, był to moment uwielbienia Matki i wywyższenia ucznia. Składając ofiarę proszono o przebaczenie grzechów. Do wydarzenia spod krzyża powracano także w post pridie, prosząc o uświęcenie darów.

$\mathrm{W}$ tradycji wizygockiej do własnych tekstów należało wprowadzenie do $M o$ dlitwy Pańskiej oraz błogosławieństwo. W modlitwie przed Pater noster przywołano wydarzenie z apokryfów, kiedy św. Jan uniknął otrucia, gdy podano mu zatruty napój. Celebrans wskazywał, że człowiek również może stać się taką trucizną przez grzech. Prosił on, aby Pan oddalił namiętność ciała i truciznę pokus odwiecznego wroga. W błogosławieństwie natomiast celebrans prosił, aby św. Jan doprowadził wiernych do prawdziwej miłości, do wzbudzenia z odrętwienia życia cielesnego, aby dostąpili bliskości Chrystusa, co ma wyrażać motyw spoczywania na piersi Jezusa. W modlitwie po Komunii św.: Gratias tibi agimus Domine... celebrans natomiast prosił, aby wierni mogli świętować w pokoju.

W dobie średniowiecza, zwłaszcza w tradycji galijskiej, znane były sekwencje na ten dzień. Przykładem jest tekst znajdujący się w Liber sequentiarum Notkera Balbulusa (zm. 912). W sekwencji: Joannes, Jesu Christo... ${ }^{41}$ wychwalano św. Apostoła, który wzgardził życiem rodzinnym idąc za Mesjaszem, a obecnie cieszy się oglądaniem Jego chwały w niebie. Wspominano również wydarzenia z życia św. Jana, kiedy Jezus na krzyżu powierzył mu pod opiekę swoją matkę. On też objawił największą tajemnicę o Słowie, które było u Boga. Przywoływano również wydarzenia z apokryfów o życiu św. Jana Ewangelisty, o wskrzeszeniu zmarłych oraz uniknięciu otrucia. Wspominając te wydarzenia proszono, aby św. Jan wszystkich wiernych polecał Bogu.

Po Soborze Trydenckim, od pierwszego wydania Missale Romanum w 1570 r., ku czci św. Jana obchodzono święto w randze święta zdwojonego (duplex) i przypisano Statio ad sanctam Mariam maiorem ${ }^{42}$. Introit, graduał, werset przed Ewangelią, offertorium oraz antyfona na Komunię św. znane były w liturgii od czasów

\footnotetext{
${ }^{41}$ Por. NotKerus Balbulus, Liber sequentiarum, PL 131, 1007.

${ }^{42}$ Por. Missale Romanum Ex Decreto Sacrosancti Concilii Tridentini restitutum Pii V. Pont. Max. iussu editum, Romae, Apud Hęredes Bartholomęi Faletti, Joannem Uariscum, \& Socios, Anno Domini MDLXX, s. 27-28.
} 
średniowiecza i występowały w antyfonarzu św. Grzegorza Wielkiego drugiej mszy ku czci św. Jana ${ }^{43}$. Wszystkie natomiast modlitwy również występowały w Sakramentarzu Gregoriańskim - Hadriańskim. Czytania biblijne po Soborze Trydenckim odwołują się do wcześniejszych ksiąg, choć obejmowały inne wersety. Epistołę tworzyły teksty Księgi Mądrości Syracha (15,1-6), a Ewangelię perykopa z Ewangelii Jana (21,19-24). W epistole proklamowano prawdę, że kto trzyma się prawa, ten posiądzie mądrość. On też zostanie nakarmiony chlebem rozumu i napojony wodą mądrości. Będzie przemawiał pośród zgromadzenia i znajdzie wesele i wieniec uniesienia oraz odziedziczy wieczne imię. W Ewangelii natomiast przywoływano wydarzenia po zmartwychwstaniu, kiedy Pan trzykrotnie zapytał św. Piotra o miłość do Niego i zlecił mu posługę przewodzenia wspólnocie Kościoła. Św. Jan dał temu świadectwo, a jego świadectwo jest prawdziwe.

W wyniku reform Mszału Rzymskiego teksty te nie uległy zmianie. Te same modlitwy i czytania występowały w ostatnim wydaniu Mszału Rzymskiego, które ukazało się w 1962 r. i było owocem reform przeprowadzonych za pontyfikatu

\footnotetext{
${ }^{43}$ Według antyfonarza przypisywanego św. Grzegorzowi Wielkiemu (590-604) w ten dzień sprawowano dwie msze. Pierwszą mszę rozpoczynano od introitu: Ego autem sicut oliva fructifera in domo Dei (Ps 52 [51], 10) wraz z wersetem psalmu: Quid gloriaris in malitia, qui potens es in iniquitate? (Ps 52 [51], 3). Graduał tworzyły słowa: Justus ut palma florebit, sicut cedrus Libani multiplicabitur in domo Domini (Ps 92 [91], 13) wraz z wersetem: Bonum est confiteri Domino, et psallere nomini tuo, Altissime (Ps 92 [91], 2). Podczas ofertorium śpiewano antyfonę: Gloria et honore coronasti eum, et constituisti eum super opera manuum tuarum, Domine (Hbr 2,7) - wraz z wersetami Psalmu 8: Domine Dominus noster... Na Komunię św. śpiewano natomiast antyfonę: Magna est gloria ejus in salutari tuo (Ps 21 [20], 6) wraz z wersetami tego psalmu. Podczas drugiej mszy w ten dzień Introit brzmiał: In medio Ecclesiae aperuit os ejus, et implevit eum Dominus spiritu sapientiae et intellectus; stolam gloriae induit eum (Syr 15,5-6), wraz z wersetem: Bonum est confiteri Domino, et psallere nomini tuo, Altissime (Ps 92[91],2). Graduał natomiast tworzyły wersety: Exiit sermo inter fratres, quod discipulus ille non moritur. Sic eum volo manere donec veniam, tu me sequere (J 21,23.22). W wersecie przed Ewangelią: Hic est discipulus ille, qui testimonium perhibuit de his, et scimus quia verum est testimonium ejus (J 21,24). W czasie offertorium śpiewano antyfonę wraz z trzema wersetami: Justus ut palma florebit; sicut cedrus quae in Libano est multiplicabitur. Vers. 1. Bonum est confiteri Domino, et psallere nomini tuo, Altissime. Vers. 2. Ad annuntiandum mane misericordiam tuam, et veritatem tuam per noctem. Vers. 3. Plantati in domo Domini, in atriis domus Dei nostri florebunt (Ps 92[91],13.2.3.14). Antyfona po Komunii św. nawiązywała do wydarzenia z życia św. Jana: Exiit sermo inter fratres quod discipulus ille non moritur, et non dixit Jesus: Non moritur, sed sic eum volo manere donec veniam (J 21,23). Antyfony podczas tych dwóch mszy były niezmienne w późniejszych wiekach, o czym świadczą antyfonarze z Mont-Blandin (VIII/IX w.), z Compiègne (IX w.), z Corbie (IX/X w.) oraz z Senlis (IX w.). W antyfonarzu z Monza (VIII w.) podano tylko same teksty śpiewów międzylekcyjnych, a w antyfonarzu z Rheinau (VIII/IX w.). jedynie teksty antyfon drugiej Mszy św. ku czci św. Jana Apostoła; por. GREGORIUS I, Liber antiphonarius. Ordinatus per circulum anni, PL 78, 647-648; R.J. HeSBERT, Antiphonale Missarum sextuplex, Rome 1935, s. 18-19.
} 
papieża Jana XXIII (1958-1963) ${ }^{44}$. Niezmienność tekstów w kościele rzymskim obowiązywała więc przez 400 lat.

\section{TEKSTY MSZALNE KU CZCI ŚW. JANA APOSTOŁA I EWANGELISTY ANTE PORTAM LATINAM}

Drugim świętem ku czci św. Jana był dzień 6 maja. W sakramentarzu Gregoriańskim - Hadriańskim odpowiedni formularz znajduje się w sekcji 104 i został zatytułowany: Pridie Nonas Maias Id Est VI Die Mensis Maii Natale Sancti Iohannis Ante Portam Latinam ${ }^{45}$. W oracji tego dnia: Deus, qui conspicis... zwracając się do Boga, który widzi, że zło otacza ludzi zewsząd, proszono, aby chwalebne wstawiennictwo św. Jana osłaniało przed tym niebezpieczeństwem. W modlitwie nad darami: Muneribus nostris... proszono, aby dary i modlitwy oczyściły wiernych. Pokrzepienie natomiast Chlebem niebiańskim, słowami modlitwy: Refecti domine... kapłan prosił, aby ten dar służył ku życiu wiecznemu.

Formularz święta ku czci św. Jana, które obchodzono w maju, zapisano w Sakramentarzu Triplex ${ }^{46}$. Oprócz tekstów zaczerpniętych z Sakramentarza Gregoriańskiego - Hadriańskiego znalazły się w tym formularzu do wyboru inna secreta oraz modlitwa po Komunii św. (ad complendum). W sekrecie: Sacrificium nostrum... proszono, aby św. Jan polecał ofiarę, która miała być przyjęta dla Jego zasług. W modlitwie ad complendum: Sumpsimus domine... wstawiennictwo św. Jana miało wyjednać przebaczenie win.

W liturgii pozarzymskiej wiele własnych tekstów znajdowało się w Missale Gothicum. Święto to zostało umieszczone po święcie odnalezienia Krzyża Świętego. Występujące tu teksty znane były już w Libelli z Werony, jak: oracja Omnipotens sempiterne deus..., Deus, qui per os beati Iohannis..., czy immolacio, a więc prefacja. Do własnych tekstów należały modlitwy post nomina oraz ad pacem. W pierwszej z nich: Praesta, omnipotens deus... celebrans prosil, aby Odwieczne Słowo, które stało się ciałem, zawsze mieszkało wśród wierzących. W drugiej z tych modlitw: Pacem tuam... celebrans prosił, aby pokój przekazany przez Zmartwychwstałego Pana zawsze pozostawał niewzruszony w sercach wierzących. W mszale mozarabskim wskazano, że teksty liturgiczne należało zaczerpną́ z 27 grudnia ${ }^{47}$.

\footnotetext{
${ }^{44}$ Por. Missale Romanum ex decreto SS. Concilii Tridentini Restitutum Summorum Pontificum cura recognitum, Editio Typica, Typis Polyglottis Vaticanis 1962, s. 25-27.

${ }^{45}$ Por. J. Deshusses, Le Sacramentaire Gregorien, s. 216.

${ }^{46}$ Por. O. Heiming, Das Sacramentarium Triplex, s. 150-151.

${ }^{47}$ Por. Liturgia mozarabica secundum regulam beati Isidori, Missale Mixtum, PL 85, 745.
} 
Po Soborze Trydenckim utrwalono teksty liturgiczne na dzień 6 maja. Obchodzono je w randze duplex ${ }^{48}$. Wszystkie modlitwy tego formularza były zaczerpnięte z Sakramentarza Gregoriańskiego - Hadriańskiego. Do własnych tekstów należały antyfony i czytania. W introicie: Protexisti me, Deus... błagano o ukrycie prześladowanego przed zgrają złoczyńców, aby mógł zachować życie od strachu przed wrogiem. W graduale: Justus ut palma florebit... przypominano, że sprawiedliwy rozkrzewi się jak palma, wyrośnie jak cedr Libanu i zakwitnie przed Panem jak lilia. Podczas offertorium: Confitebuntur... podkreślano, że niebiosa wysławiają cuda Pana i jego wierność pośród świętych. Dlatego w antyfonie na Komunię św.: Laetabitur iustus... przypomniano, że sprawiedliwy będzie radował się w Panu i chlubił się będzie z prawego serca. Czytania biblijne korespondują z postacią i życiem św. Jana. Epistoła została zaczerpnięta z Księgi Mądrości (5,1-5) i odczytywano ją podczas wspomnienia o męczenniku w czasie Wielkanocy. Podkreślając znaczenie prześladowań i męczeństwa, wskazywano na zwycięstwo świętego, który został zaliczony do synów Bożych. Perykopa ewangeliczna przypominała natomiast wydarzenie, kiedy matka synów Zebedeusza prosiła Jezusa o zaszczytne miejsce w Jego królestwie dla swoich synów. Zasada ta wyznacza postawę służby wobec innych na wzór Syna Człowieczego (por. Mt 20,20-28). Teksty liturgiczne, przeznaczone na ten dzień świąteczny, wprawdzie były uboższe niż na święto In Natale św. Jana, ale dopełniały one obraz liturgicznego świętowania ku czci tego Świętego.

\section{ZAKOŃCZENIE}

Teksty liturgiczne, przewidziane na święto św. Jan Ewangelisty, pozwalają na ukazanie istotnych treści związanych z kultem tego Świętego w liturgii Kościoła do reformy Soboru Trydenckiego. Centrum tego kultu stanowi Eucharystia, dlatego spojrzenie na celebracje Mszy św. przez pryzmat tekstów mszalnych pozwala ukazać miejsce tego Świętego w misterium liturgii, a szczególnie jego orędownictwo. W tradycji zachodniej obchodzono dwa święta ku czci św. Jana Ewangelisty, zarówno dzień narodzin dla nieba, 27 grudnia, oraz wspomnienie jego męczeństwa 6 maja. W kształtowaniu się kultu św. Jana oprócz przekazów biblijnych ważną rolę odegrały apokryfy Nowego Testamentu, w których jednak wiele przekazów miało charakter legendarny.

Najstarsze teksty liturgiczne, utrwalone w średniowiecznych księgach liturgicznych, świadczą o bogactwie i różnorodności tekstów mszalnych przepisanych

\footnotetext{
${ }^{48}$ Por. Missale Romanum Ex Decreto Sacrosancti Concilii Tridentini restitutum, s. 42-43.
} 
na obchodzenie świąt ku czci św. Jana Ewangelisty. Większa różnorodność tekstów liturgicznych dotyczyła święta obchodzonego 27 grudnia. Wyrazem tego są zmienne dwa formularze do wyboru, jak w przypadku Libelli z Werony czy Sakramentarzu Triplex. Mniejszy wybór tekstów znalazł się w Sakramentarzu Gregoriańskim - Hadriańskim, które to teksty zostały utrwalone po reformie Soboru Trydenckiego. Niezmiennym również tekstem była Ewangelia, w której przypominano wydarzenia po zmartwychwstaniu, kiedy Pan trzykrotnie zapytał św. Piotra o miłość do Niego i zlecił mu posługę przewodzenia wspólnocie Kościoła.

Na uwagę zasługują teksty średniowiecznej liturgii mszalnej spoza liturgii rzymskiej. Przykładem jest liturgia galijska, która znana była do czasów reformy przeprowadzonej za Pepina Małego i Karola Wielkiego. Reprezentantem tamtej liturgii jest Missale Gothicum, w którym na poszczególne dni liturgiczne przewidywano wiele zmiennych części. Należy tu podkreślić, że według Missale Gothicum święto In Natale dotyczyło razem świętych Jakuba i Jana. Podobnie wiele tekstów własnych występowało na ten dzień w Mszale mozarabskim. W liturgii galijskiej przed Soborem Trydenckim znano również sekwencję przeznaczoną na ten dzień. O wiele uboższy wybór tekstów towarzyszył świętowaniu 6 maja, w tradycji rzymskiej, aż do reformy Soboru Trydenckiego, były niezmienne teksty występujące w Sakramentarzu Gregoriańskim - Hadriańskim.

Teksty mszalne ukazują św. Jana przede wszystkim jako Apostoła, Ewangelistę, nauczyciela, przewodnika i orędownika. Najczęściej z biblijnych przekazów w formularzach mszalnych widnieje jego powołanie jako rybaka ludzi, szczególna relacja z Chrystusem, czego wyrazem jest spoczywanie na piersi Jezusa w czasie Ostatniej Wieczerzy, przekazanie pod jego opiekę Matki Pana. Wskazując na Jego naukę często odwoływano się do głoszonego przez niego odwiecznego Słowa, które od początku było u Boga. W tekstach liturgicznych odwoływano się także do apokryfów, a najwięcej odniesień można odnaleźć w tekstach tradycji wizygockiej. Do motywu męczeństwa św. Jana nawiązywały teksty święta obchodzonego 6 maja.

W formularzach mszalnych dotyczących dwóch świąt ku czci św. Jana Ewangelisty podkreślano jego rolę jako orędownika. Wstawiennictwo św. Jana odnosiło się do dóbr doczesnych i wiecznych. W modlitwach błagano, aby wierni mogli zrozumieć naukę przekazaną przez św. Jana i umiłować to, w co On wierzył i głosił, czego nauczał. Oznaczało to dojście do poznania Odwiecznego Słowa, a dzięki misterium Eucharystii zawsze Ono zamieszkało wśród wiernych. Skoro wierni nie mogą w pełni naśladować ich czynów, powinni przynajmniej starać się naśladować ich napomnienia. Naśladowanie Apostołów miało dotyczyć ich postawy modlitwy i głoszenia nauki, aby to ziarno wydało plon w wieczności. W sposób konkretny dobra doczesne dotyczyły odpuszczenia 
kar, wyzwolenia od zła, wyjednania przebaczenia, trwania w bojaźni, opieki Świętego, oddalenia namiętności i trucizny złego ducha, doprowadzenie do prawdziwej miłości i zażyłości z Chrystusem, a tym samym wyprowadzenia z odrętwienia życia cielesnego. Wstawiennictwo to odnosiło się do całego stworzenia, aby ziemia wydała owoce, a dusza została przybrana cnotami. Dobra wieczne natomiast dotyczyły osiągnięcia zbawienia i doświadczenia daru miłosierdzia Boga.

Lektura tekstów liturgicznych ku czci św. Jana Ewangelisty pozwala ukazać tego Świętego w misterium Kościoła jako wzór zjednoczenia z Chrystusem i Jego Matką oraz orędownika w codzienności życia wiernych. Poznanie tych tekstów liturgicznych, z uwzględnieniem kształtowania się kultu św. Jana Ewangelisty, pozwoli odkrywać bogactwo ich wstawiennictwa i wzoru we wspólnocie wierzących.

\section{BIBLIOGRAFIA}

Acta Sanctorum Novembris, collecta digesta illustrata, a Carolo de Smedt, Iosepho de Backer, Francisco van Ortroy, Iosepho van den Gheyn, Hippolyto Delehaye \& Alberto Poncelet, Societatis Iesu Presbyteris. Tomi II pars prior, qua dies tertius partim et quartus continentur praemissum est Martyrologium Hieronymianum edentibus Iohanne Baptista de Rossi et Ludovico Duchesne, Bruxellis 1894.

Auf der Maur H., Feste und Gedenktage der Heiligen, w: H.B. MeYer (red.), Gottesdienst der Kirche. Handbuch der Liturgiewissenschaft, t. VI/1, Regensburg 1994, s. 67-296.

Boguniowski J.W., Rozwój historyczny ksiag liturgii rzymskiej do Soboru Trydenckiego i ich recepcja w Polsce, Kraków 2001.

Deshusses J., Le Sacramentaire Gregorien. Ses Principales Formes d'apres les plus anciens Manuscrits, v. 1, Fribourg 1971.

Dold A., Gamber K., Das Sakramentar von Monza (Im cod. F1/101 der dortigen Kapitelsbibliothek), Beuron 1957.

EIzenhöFer L., Siffrin P., Mohlberg L.C., Sacramentarium Veronense (Cod. Bibl. Capit. Veron. LXXXV [80]), Roma 1994.

FrANZ A., Die kirchlichen Benediktionen im Mittelalter, t. I, Freiburg 1909.

Fros H., Kult świętych w rozwoju historycznym $i$ w liturgii Kościoła, w: TENŻE, Wprowadzenie do Mszy o świętych, cz. 1, Warszawa 1980, s. 16-101.

Fros H., Sowa F. (opr.), Księga imion i świętych, t. III, Kraków 1998.

GREGORIUS I, Liber antiphonarius. Ordinatus per circulum anni, PL 78, 641-724.

GREGORIUS NysSENUS, Oratio funebris qua fratris sui Basilii Magni laudes et memoriam concelebrat, PG 46, 787-818.

Gvillelmi Dvranti Rationale divinorvm officiorvm, VII-VIII, wyd. kryt. A. Davril, T.M. Thibodeau, Turnhout 2000.

Heiming O., Das Sacramentarium Triplex. Die Handschrift C 43 der Zentralbibliothek Zürich, B. I-II, Münster 1968-1983.

HeINZ A., Liturgien. IV. Abendländische Liturgien. 2. Altspanische Liturgie, LThK VI, Freiburg im Breisgau 1997, kol. 982-983. 
HESBERT R.J., Antiphonale Missarum sextuplex, Rome 1935.

Honorius Augustodunensis, Gemma animae sive de divinis officiis et antiquo ritu missarum, deque horis canonicis et totius annis solemnitatibus, PL 172, 541-737.

JoANNES BelETHus, Rationale divinorum officiorum, PL 202, 9-166.

Księga Pontyfików 1-96, (Synody i Kolekcje Praw, IX), opr. M. Ożóg, H. Pietras, Kraków 2014.

LeSke A., Ewangelia wedtug św. Mateusza, w: Międzynarodowy komentarz do Pisma Świętego, red. W.R. Farmer, Warszawa 2001, s. 1140-1209.

Liturgia mozarabica secundum regulam beati Isidori. Missale Mixtum, PL 85, 109-1055.

Missale Romanum Ex Decreto Sacrosancti Concilii Tridentini restitutum Pii V. Pont. Max. iussu editum, Romae, Apud Hęredes Bartholomęi Faletti, Joannem Uariscum, \& Socios, Anno Domini MDLXX.

Missale Romanum ex decreto SS. Concilii Tridentini Restitutum Summorum Pontificum cura recognitum, Editio Typica, Typis Polyglottis Vaticanis 1962.

Mohlberg L.C. (wyd.), Missale Gothicum (Vat. Reg. lat. 317), Roma 1961.

Mohlberg L.C., Liber Sacramentorum Romanae Aeclesiae ordinis anni circuli (Cod. Vat. Reg. lat. 316/Paris Bibl. Nat. 7193, 41/56 Sacramentarium Gelasianum), Roma 1960.

NADOLSKi B., Galijski ryt, EK V, Lublin 1989, kol. 821-822.

NotKerus Balbulus, Liber sequentiarum, PL 131, 1003-1026.

PAŁĘCKI W., Sakramentarz, EK XVII, Lublin 2012, kol. 901-903.

RighetTi M., L'anno Liturgico, (Manuale di storia liturgica, t. II), Milano 1969.

S. Congregatio Rituum, Variationes in Breviario et Missali Romano ad normam novi Codicis Rubricarum, AAS 52(1960), s. 706-721.

STACHOWIAK L., Jan apostot Ewangelista. I. W Piśmie św., EK VII, kol. 752-753.

Starowieyski M. (red.), Apokryfy Nowego Testamentu, t. II, cz. I, Kraków $2017^{2}$.

STRASZEWICZ M., Jan apostot Ewangelista. II. Kult, EK VII, kol. 753-754.

Św. Augustyn, Homilie na Ewangelie i Pierwszy list Św. Jana, cz. II, (Pisma starochrześcijańskich pisarzy, t. XV), Warszawa 1977.

WiT Z., Troska liturgiczna o człowieka chorego $w$ świetle polskich rytuałów potrydenckich (1631-1964), Lublin 1995.

\section{W SWOIM KOŚCIELE PAN OTWORZYŁ JEGO USTA (POR. SYR 15,5). \\ OREDOWNICTWO ŚW. JANA APOSTOŁA I EWANGELISTY W ŚWIETLE FORMULARZY MSZALNYCH KOŚCIOŁA ZACHODNIEGO DO SOBORU TRYDENCKIEGO}

\section{STRESZCZENIE}

Od pierwszych wieków chrześcijaństwa kult świętych był nierozdzielnie związany z misterium Chrystusa. Zwłaszcza na początku oddawano szczególną cześć Matce Jezusa i najbliższym uczniom Chrystusa Pana. Jednym z tych uczniów Pana należących do grona Dwunastu, którego kult znany był od pierwszych wieków chrześcijaństwa, jest św. Jan Ewangelista. W tradycji zachodniej obchodzono dwa święta ku Jego czci: dzień narodzin dla nieba, 27 grudnia, oraz wspomnienie poddania go torturom, 6 maja. W kształtowaniu się kultu św. Jana oprócz przekazów biblijnych ważną rolę odegrały 
apokryfy Nowego Testamentu. Najczęściej z biblijnych przekazów w formularzach mszalnych przywoływano powołanie św. Jana jako rybaka ludzi, jego szczególną relację z Chrystusem podczas Ostatniej Wieczerzy oraz przekazanie pod jego opiekę Matki Pana. Wskazując na Jego naukę często odwoływano się do głoszonego przez niego Odwiecznego Słowa, które od początku było u Boga. Lektura tekstów liturgicznych ku czci św. Jana Ewangelisty pozwoliła ukazać tego Świętego w misterium Kościoła jako wzór zjednoczenia z Chrystusem i Jego Matką, oraz jako orędownika w codzienności życia wiernych.

Słowa kluczowe: liturgia; kult świętych; Eucharystia; św. Jan Apostoł i Ewangelista. 